\title{
USIA IBU SAAT HAMIL DAN KEJADIAN STUNTING PADA ANAK USIA 1-3 TAHUN
}

\author{
Tri Nurhidayati ${ }^{1}$, Heny Rosiana ${ }^{2}$, Rozikhan $^{3}$ \\ 1,2,3 UPP Kampus Kendal, Poltekkes Kemenkes Semarang, Indonesia
}

\begin{abstract}
One of the nutritional problems at this time is the high stunting of child in under five years. Stunting caused by a multidimensional factor and not only caused by malnutrition experienced by pregnant women and children under five. Other factors that affect the mother are the mother's posture (short), the pregnancy is too close, the mother is still a teenager and the lack of nutritional intake during pregnancy. This study aims to analyze the relationship between the age of pregnant women and the incidence of stunting. This type of research is analytic observational with a case control design, the number of samples is 80 respondents, namely mothers who have children aged 1-3 years (40 cases and 40 controls). Data analysis used univariate and bivariate analysis. Maternal age at pregnancy did not significantly influence the incidence of stunting $p$ value 0.368 . The conclusion is that the mother's age at pregnancy hasn't a risk of stunting in children who are born.
\end{abstract}

Keyword : Age Of Pregnant Women; Stunting; Child 


\section{PENDAHULUAN}

Permasalah gizi masih dialami oleh bangsa Indonesia dengan dampak serius terhadap kualitas Sumber Daya Manusia (SDM). Salah satunya adalah masih tingginya kasus anak balita pendek (stunting). (Buku Saku Desa dalam Penanganan Stunting). Hasil Penilaian Status Gizi (PSG) tahun 2017 dengan melihat status gizi Balita berdasarkan Indeks Tinggi Badan/Umur (TB/U) didapatkan balita dengan usia 0-59 bulan dengan status sangat pendek sebesar 9,8 $\%$, pendek 19,8. Angka ini meningkat dibandingkan dengan hasil PSG tahun 2016 dengan persentase balita sangat pendek sebesar 8,6\% dan pendek sebesar 19,0\%. Sedangkan pada balita usia $0-23$ bulan persentase sangat pendek sebesar 6,9 \% dan pendek sebesar 13,2 \%. Persentase stunting/pendek (sangat pendek dan pendek) pada kelompok balita $(29,6 \%)$ lebih tinggi dibandingkan kelompok baduta $(20,1 \%)$. Angka kejadian di propinsi Jawa Tengah pada balita usia 0 - 59 bulan sangat pendek 7,9 \% dan pendek $20,6 \%$. Sedangkan pada balita usia $0-23$ bulan dengan angka kejadian sangat pendek sebesar $5,5 \%$ dan pendek 12,9\% (Kementerian Kesehatan RI, 2017)

Stunting didefinisikan sebagai indeks tinggi badan menurut umur (TB/U) kurang dari minus dua standar deviasi (-2SD) atau dibawah rata-rata standar yang ada dan severe stunting didefinisikan kurang dari -3SD (Kemenkes RI,2011). Faktor multidimensi diduga sebagai factor yang mempengaruhi kejadian stunting. Selain itu, faktor gizi buruk yang dialami oleh ibu hamil maupun anak balita juga ikut berkontribusi terjadinya stunting pada balita. Praktik pengasuhan yang kurang baik, kurangnya pengetahuan ibu mengenai kesehatan dan gizi, terbatasnya layanan kesehatan termasuk layanan pemeriksaan kehamilan/ANC, masih kurangnya akses rumah tangga/keluarga ke makanan bergizi dan kurangnya akses ke air bersih dan sanitasi (Tim Nasional Percepatan Penanggulaangan Kemiskinan, 2017).

Penelitian Ni'mah dan Nadhiroh (2015) yang dilakukan di wilayah kerja Puskesmas Tanah Kali Kedinding dengan jumlah sampel 34 balita, didapatkan hasil bahwa bayi lahir dengan panjang badan rendah/kurang, tanpa pemberian ASI Eksklusif, pendapatan keluarga, pendidikan ibu dan pengetahuan ibu yang rendah merupakan faktor yang berhubungan dengan kejadian stunting pada balita.

Faktor lain yang ikut mempengaruhi terjadi stunting seperti keadaan kesehatan dan status gizi ibu sebelum hamil dan saat hamil. Kondisi ibu pasca melahirkan juga ikut berperan dalam pertumbuhan dan risiko terjadinya stunting. Ibu dengan postur pendek, jarak kehamilan terlalu dekat ( $<2$ tahun), kehamilan remaja dan konsumsi nutrisi selama kehamilan juga harus dikaji karena dapat menyebabkan 
stunting. Usia Ibu dibawah 20 tahun berisiko melahirkan bayi dengan berat lahir rendah (BBLR). Bayi BBLR mempengaruhi sekitar $20 \%$ dari terjadinya stunting (Kemenkes, 2018). Hal ini sesuai dengan penelitian yang dilakukan oleh Rahayu, dkk (2015), bahwa bayi dengan BBLR mempunyai risiko 5,87 kali untuk mengalami stunting.

Pengaruh stunting jangka pendek antara lain terganggunya perkembangan otak, kecerdasan, gangguan pertumbuhan fisik dan gangguan metabolisme dalam tubuh. Sedangkan dampak jangka panjang seperti menurunnya kemampuan kognitif dan prestasi belajar, menurunnya kekebalan tubuh yang mengakibatkan mudah terserang penyakit dan risiko munculnya penyakit pada usia tua meliputi diabetes, kegemukan, penyakit jantung, pembuluh darah, kanker, stroke dan disabilitas (Kementerian Desa, Pembanguan daerah Tertinggal dan Transmigrasi, 2017)

\section{METODOLOGI PENELITIAN}

Jenis penelitian ini adalah observasional analitik dengan desain case control Penelitian dilaksanakan di wilayah Puskesmas Pegandon Kabupaten Kendal. Kegiatan penelitian dilaksanakan mulai dari Juni - November 2019. Sampel dalam penelitian ini harus memenuhi kriteria inklusi yaitu batita dengan stunting (kelompok kasus) dan batita tidak stunting (kelompok control). Besar Sampel dalam penelitian ini adalah 80 balita (40 balita stunting dan 40 balita tidak stunting). Analisis data dengan univariat dan bivariate menggunakan SPSS for windows.

\section{HASIL PENELITIAN DAN BAHASAN}

Tabel 1. Distribusi Frekuensi Responden Berdasarkan Usia Saat Hamil di Wilayah Puskesmas Pegandon Kendal

\begin{tabular}{lll}
\hline Variabel & Jumlah & $\%$ \\
\hline Usia Ibu & & \\
$<20$ thn $/>35$ thn & 18 & 22,5 \\
$20-35$ thn & 62 & 77,5 \\
\hline
\end{tabular}

Hasil penelitian variable yang diteliti menunjukkan bajwa dari 80 responden terdapat 18 responden (22,5\%) yang berusia kurang dari 20 tahun atau lebih dari 35 tahun dan 62 responden $(77,5 \%)$ yang berusia 20-35 tahun.

Tabel 2. Distribusi Hubungan Antara Usia Ibu Saat Hamil dengan Kejadian Stunting di Wilayah Puskesmas Pegandon Kendal

\begin{tabular}{|c|c|c|c|c|c|c|c|}
\hline \multirow{3}{*}{ Usia ibu } & \multicolumn{4}{|c|}{ Kejadian Stunting } & \multicolumn{2}{|c|}{ Total } & \multirow{3}{*}{$\begin{array}{c}\text { Nilai } \\
p\end{array}$} \\
\hline & \multicolumn{2}{|c|}{ Stunting } & \multicolumn{2}{|c|}{$\begin{array}{c}\text { Tidak } \\
\text { stunting }\end{array}$} & \multirow[b]{2}{*}{$\mathrm{n}$} & \multirow[b]{2}{*}{$\%$} & \\
\hline & $\mathrm{n}$ & $\%$ & $\mathrm{n}$ & $\%$ & & & \\
\hline$<20$ thn $/>$ & 10 & 25 & 8 & 20 & 18 & 100 & \\
\hline 35 thn & & & & & & & 0,368 \\
\hline 20-35 thn & 30 & 75 & 32 & 80 & 62 & 100 & \\
\hline Jumlah & 40 & & 40 & & 80 & & \\
\hline
\end{tabular}

Hasil analisa data terkait dengan usia ibu saat hamil didapatkan hasil $p$ value > 0,05 . Hal tersebut menunjukkan bahwa tidak ada hubungan antara usia ibu saat hamil dengan kejadian stunting 
Pembahasan

Hasil analisis berkaitan dengan usia saat hamil dengan kejadian stunting didapatkan hasil $p$ value 0,368. Hasil analisa dari data yang didapatkan tersebut menunjukkan bahwa ibu hamil yang berusia kurang dari 20 tahun atau lebih dari 35 tahun tidak berhubungan dengan terjadinya stunting.

Proses kehamilan sangat dipengaruhi oleh usia ibu ketika didiagnosa hamil. Apabila usia ibu saat hamil lebih muda atau lebih tua maka akan berisiko mengalami komplikasi kehamilan. Seorang wanita yang hamil pada usia remaja akan mendapat early prenatal care lebih sedikit. Kurangnya asuhan yang diperoleh inu karena kehamilan remaja diprediksi menyebabkan bayi lahir dengan berat rendah (BBLR) serta kematian bayi. Sebagian besar remaja putri yang hamil dengan Indeks Masa Tubuh (IMT) kurang dari normal (underweight) memiliki risiko untuk melahirkan bayi dengan BBLR Kurangnya asupan gizi karena kekhawatiran pada bentuk tubuh selama masa remaja dan kurangnya pendidikan tentang gizi dicurigai sebagai factor kurangnya IMT pada kehamilan remaja. Kedua hal tersebut mengakibatkan rendahnya kenaikan BB ibu selama masa kehamilan yang berakibat pada kenaikan jumlah bayi lahir prematur yang menjadi salah satu penyebab faktor stunting pada balita (Vivatkusol Y, 2017).

Penelitian Larasati, dkk (2018) menunjukkan bahwa Ibu hamil pada usia remaja berisiko 3,86 lebih besar mengalami stunting dibandingkan dengan balita yang lahir dari ibu yang hamil diusia normal. Usia ibu hamil (maternal age) sebaiknya tidak terlalu muda dan tidak terlalu tua. Ibu hamil dengan usia kurang dari 20 tahun atau lebih dari 35 tahun berisiko tinggi untuk melahirkan. Kehamilan di bahwa usia 20 tahun akan berisiko terjadinya kekurangan sel darah merah/anemia, gangguan pertumbuhan dan perkembangan janin, keguguran/abortus, prematuritas atau BBLR, gangguan pada saat proses persalinan, preeklamsi / keracunan kehamilan dan perdarahan antepartum (Puskesmas Yogyakarta, 2018)

Sejalan dengan penelitian Indrasari (2012) yang menyatakan bahwa ibu dengan usia berisiko (kurang dari 20 tahun) mempunyai risiko 4,2 kali lebih besar untuk mengalami terjadinya BBLR. Kejadian BBLR dan kelahiran prematur pada remaja sering dikaitkan sebagai manifestasi Intra uterine Growth Restriction (IUGR) yang disebabkan belum matangnya organ reproduksi da status gizi sebelum masa kehamilan. Kehamilan di usia awal remaja, ketika ibu juga masih tumbuh akan meningkatkan resiko bayi yang dilahirkan akan menjadi stunting.

Depkes RI (dalam Caludia, 2012) menggolongkan umur ibu menjadi 2 kategori, yaitu umur berisiko dan umur tidak berisiko dalam masa kehamilan. Ibu hamil termasuk kategori tidak berisiko 
adalah jika ibu berada pada kelompok umur 20-35 tahun. Sedangkan kelompok berisiko yaitu ibu hamil yang berumur $<20$ tahun dan $>35$ tahun. Secara fisiologis, kelompok ibu dengan umur di bawah 20 tahun masih dalam proses pertumbuhan, baik tinggi badan maupun berat badan. Keadaan ini tidak mendukung bagi seorang ibu untuk memasuki masa kehamilan karena berada pada masa pertumbuhan badannya sendiri sekaligus menunjang pertumbuhan janinnya. Proses ini akan menyebabkan timbulnya "kompetisi" antara ibu dan janinnya (Brown, dalam Claudia,2012). Adapun ibu dengan usia di atas 35 tahunn dianggap sudah tidak mampu lagi menerima kehamilan dikarenakan fisik yang tergolong tua untuk kehamilan dan lemah menerima beban kehamilannya.

\section{KESIMPULAN}

Usia ibu saat hamil tidak berperngaruh secara signifikan terhadap kejadian stunting ( $p$ value 0,368 ).

Disarankan untuk melakukan penelitian lebih lanjut tentang factor asuhan pada masa bayi yang dapat mempengaruhi kejadian stunting

\section{DAFTAR PUSTAKA}

1. Claudia Debtarsie K, 2012, Hubungan Status Gizi Ibu dan Faktor Lain dengan berat dan Panjan lahir Bayi di Rumah Sakit Sint Carolus Jakarta Bulan JuliSeptember 2011. Skripsi, Universitas Indonesia
2. Indrasari N., 2012, Faktor Risiko pada Kejadian Berat Badan Lahir Rendah , VIII,114-123

3. Kementerian Desa, Pembangunan Daerah Tertinggal dan Transmigrasi, 2017, Buku Saku Desa dalam Penanganan Stunting, Jakarta, Kementerian Desa, Pembangunan Daerah Tertinggal dan Transmigrasi

4. Larasati D.A., Nindya T.S., Arief Y.S., 2018, Hubungan antara Kehamilan Remaja dan Riwayat Pemberian ASI dengan Kejadian Stunting pada Balita di Wilayah Kerja Puskesmas Pujon Kabupaten Malang, Amerta Nutr : 392-401.

5. Ni'mah K, Nadhiroh S.R., 2015, Faktor yang Berhubungan dengan Kejadian Stunting pada Balita, Media Gizi Indonesia Vol 10. No.1

6. Puskemas,D.I. Kulon $S$ dan Yogyakarta, (2018) P.D.I. Gizi Indonesia, 41, 39-48

7. Rahayu A., Yulidasari F., Putri A.O., Rahman F, (2015), Riwayat Berat Badan Laahir dengan Kejadian Stunting pada Anak Usia Bawah Dua Tahun, Jurnal Kesehatan Masyarakat Nasional Vol 10 No.2

8. Tim Nasional Percepatan Penanggulangan Kemiskinan, 2017, 100 Kabupaten/Kota Prioritas untuk Intervensi Anak Kerdil (Stunting), Jakarta, Tim Nasional Percepatan Penanggulangan Kemiskinan

9. VivatkusolY., Thavarama T., Phaloprakarn C, 2017, Inappropriate Gestational Weight gain Among Teenage Pregnancies : Prevalence and Pregnancy outcomes. Int.J Womens Health 9 : 347-352 